\title{
Pengaruh Tunjangan Kinerja (TUKIN) Terhadap Kualitas Kinerja Pegawai Politeknik Kelautan Dan Perikanan Sorong
}

\author{
Saharuddin $^{1 *}$, B. Watunglawar ${ }^{2}$, Guzali Tafalas ${ }^{3}$ \\ ${ }^{1}$ Politeknik KP Sorong/Universitas Terbuka \\ *Korespondensi: saharuddin777@gmail.com
}

\begin{abstract}
The Purpase of this research is to process, analyze, prove empirically and discuss the effect of perfrormance benefits on the performance of Sorong Maritime and Fisheries Polythecnic employess. This research was conducted in September to November 2018. The author collected data through questionnaires and observation for a month. The population in this study is the Polytechnic Maritime and Fisheries totalling 66 people. This study is a study of facts in the form of opinions/opinion, attitudes, experiences or characteristics of people (respondents) as subject data in the form of primary data obtained from interviews, questionnaire and observation, also seconday data. Analysis of research data using descriptive statistics, with a view to finding strong relationship between variables through correlation analysis with regression analysis, by making comparisons by comparing the average sampel data or population. The results showed that Performance allowance (X1) with all the components of its formation did not affect on employee performance (Y), so the first hypothesis stating that performance allowance $(X 1)$ affected employee performance $(Y)$ was not proven.
\end{abstract}

Key Word: Performance allowance; employee performance, Poltek KP Sorong

\begin{abstract}
ABSTRAK
Tujuan dari penelitian ini adalah untuk mengolah, menganalisis, membuktikan secara empiris dan membahas tentang pengaruh manfaat kinerja terhadap kinerja pegawai Politeknik Kelautan dan Perikanan Sorong. Penelitian ini dilakukan pada bulan September sampai dengan November 2018. Penulis mengumpulkan data melalui kuesioner dan observasi selama satu bulan. Populasi dalam penelitian ini adalah Politeknik Kelautan dan Perikanan yang berjumlah 66 orang. Penelitian ini merupakan studi tentang fakta-fakta berupa pendapat / pendapat, sikap, pengalaman atau karakteristik orang (responden) sebagai data subjek berupa data primer yang diperoleh dari wawancara, angket dan observasi, serta data sekunder. Analisis data penelitian menggunakan statistik deskriptif, dengan maksud untuk mengetahui hubungan yang kuat antara variabel melalui analisis korelasi dengan analisis regresi, dengan membuat perbandingan dengan membandingkan rata-rata data sampel atau populasi. Hasil penelitian menunjukkan bahwa Tunjangan kinerja (X1) dengan semua komponen pembentukannya tidak berpengaruh terhadap kinerja pegawai (Y), sehingga hipotesis pertama yang menyatakan bahwa tunjangan kinerja (X1) berpengaruh terhadap kinerja pegawai (Y) tidak terbukti.
\end{abstract}

Kata Kunci: Tunjangan Kinerja; Kinerja Pegawai, Poltek KP Sorong 


\section{PENDAHULUAN}

Setiap lembaga baik pemerintah maupun organisasi swasta mulai menyadari kekurangan satu sama lain, sehingga setiap unsur di dalam lembaga tersebut harus memiliki pengetahuan dan keterampilan karena kondisi di atas menyebabkan persyaratan sumber daya manusia yang tinggi. Tantangan yang akan dihadapi oleh umat manusia di masa depan adalah menciptakan organisasi yang semakin beraneka ragam dengan tuntutan pengelolaan yang semakin efisien, efektif dan produktif. Untuk ketergantungan organisasi/lembaga menekankan pada pengembangan manajemen sumber daya manusia yang berkualitas.

Kementerian Kelautan dan Perikanan (KKP) sebagai salah satu organisasi/lembaga pemerintah yang bergerak di bidang pengembangan bidang kelautan dan perikanan di Wilayah Negara Kesatuan Republik Indonesia (NKRI) terus berupaya mengembangkan diri dalam menghadapi perubahan baik yang terjadi dari dalam maupun dari luar lembaga guna menjawab tantangan dunia yang terus berkembang dunia tidak pernah berhenti berubah dengan segala bentuknya.

Badan Riset Pengembangan Sumberdaya Manusia dan Kelautan
Perikanan (BRSDM-KP) sebagai bagian dari unit kerja di Kementerian Kelautan dan Perikanan (KKP) melalui tugas utama yaitu memformulasikan, menganalisis dan mengimplementasikan kebijakan program pengembangan sumberdaya perikanan dan manajemen pendidikan, pelatihan dan penyuluhan perikanan. BRSDM-KP mempunyai tugas melaksanakan pendidikan, pelatihan, dan penyuluhan dan Pemberdayaan Masyarakat di bidang kelautan dan perikanan sesuai dengan peraturan perundang-undangan serta menyelaraskan fungsi yaitu (1). Penyusunan kebijakan teknis rencana dan program, Pemantauan, evaluasi dan pelaporan pelaksanaan pendidikan, pelatihan dan penyuluhan di bidang kelautan dan perikanan; (2) Pelaksanaan administrasi Badan Pengembangan SDM KP.

Untuk mendukung tugas, pokok dan fungsinya, BPSDM-KP memiliki Satuan Pendidikan yang terdiri dari: Sekolah Tinggi Perikanan, 3 (tiga) Politeknik Kelautan dan Perikanan yaitu Poltek KP Sidoarjo, Poltek KP Bitung, dan Poltek KP Sorong, 8 (delapan) Sekolah Usaha Perikanan Menengah dan 6 (enam) Balai Diklat Perikanan yang berlokasi di beberapa kota di seluruh Indonesia (http://www.bpsdmkp.kkp.go.id/index.php/ 
profil, 2018). Sebagai lembaga pendidikan tinggi dibawah naungan KKP. Politeknik Kelautan dan Perikanan Politeknik KP Sorong (Eks. Akademi Perikanan dan Kelautan Sorong atau yang disingkat APSOR) menyelenggarakan 3 Program Studi yaitu: Program Studi Teknologi Penangkapan Ikan (TPI) dan Program Studi Mesin dan Peralatan Perikanan, dan Program Studi Akuakultur atau sekarang dikenal dengan Program Studi Teknologi Budidaya Perikanan (https://polteksorong.kkp.go.id, 2018).

Pegawai sebagai elemen penting dalam suatu unit organisasi berperan menjalankan tugas dan fungsi (tupoksi) sesuai dengan keahliannya masing-masing. Pentingnya motivasi dalam bekerja menjadi faktor pendorong bagi pegawai guna meningkatkan etos kerja yang nantinya akan berdampak bagi peningkatan kinerja organisasi atau instansi tersebut dalam mencapai visi, misi, dan tujuan organisasi. Najoan, dkk., (2018) mengatakan bahwa pegawai di dalam melaksanakan pekerjaannya terkadang mencapai titik jenuh sehingga hal ini akan mempengaruhi proses pencapaian tujuan organisasi. Olehnya itu sebagai upaya meningkatkan kinerja dan menjadi motivasi bagi pegawai adalah dengan pemberian Tunjangan Kinerja (Tukin) yang berguna meningkatkan kesejahteraan pegawai, dan memacu semangat pegawai dalam melaksanakan tanggung jawab atas pekerjaannya dengan cepat dan benar. Lebih lanjut (Najoan, dkk., 2018) mengatakan bahwa tukin merupakan salah satu implementasi pemberian kompensasi atau imbalan yang layak atas kinerja atau prestasi kerja, penghargaan berupa tambahan penghasilan yang diberikan kepada pegawai atas kinerjanya dengan tujuan untuk meningkatkan semangat kerja pegawai.

$$
\text { Pemberian tunjangan kinerja }
$$
menurut Peraturan Pemerintah Nomor 58 Tahun 2005 tentang Pengelolaan Keuangan Daerah pada Pasal 63 menegaskan "Pemerintah daerah dapat memberikan tambahan penghasilan kepada pegawai negeri sipil daerah berdasarkan pertimbangan yang objektif dengan memperhatikan kemampuan keuangan daerah dan memperoleh persetujuan DPRD sesuai dengan ketentuan peraturan perundang-undangan”.

Oleh karena itu, penulis melakukan penelitian yang berjudul: "Tunjangan Kinerja Berpengaruh Signifikan terhadap Kinerja Pegawai Poltek KP Sorong. Adapun tujuan pada penelitian ini adalah Tujuan penelitian adalah untuk mengolah, menganalisis, membuktikan secara empiris 
dan membahas: Pengaruh tunjangan kinerja terhadap kinerja pegawai Poltek KP Sorong.

\section{METODE}

Penelitian ini bertujuan untuk menggambarkan tentang Pengaruh Tunjangan Kinerja (TUKIN) Terhadap Kualitas Kinerja Pegawai yang ada pada kantor Politeknik Kelautan dan Perikanan kota Sorong, dengan melihat pada persebaran populasi yang ada. Populasi adalah wilayah generalisasi yang terdiri atas; obyek atau subyek yang mempunyai kuantitas dan karakteristik tertentu yang ditetapkan oleh peneliti untuk dipelajari dan kemudian ditarik kesimpulannya (Sugiyono, 2010: 80). Populasi dalam penelitian ini adalah Politeknik Kelautan dan Perikanan Sorong berjumlah 66 orang. Dari populasi pegawai yang berjumlah 66 yang diambil sebagai sampel berjumlah 56 dengan tingkat kesalahan $5 \%$ sesuai dengan teori Slovin, yang menyatakan bahwa, bila semakin besar tingkat kesalahan maka semakin kecil jumlah sampel. Sebaliknya, semakin kecil tingkat kesalahan semakin besar anggota sampel yang dibutuhkan.

Instrumen penelitian ini merupakan alat ukur. Sugiyono (2013: 178) mendiskripsikanya sebagai alat yang digunakan untuk mengukur fenomena alam maupun sosial yang diamati. Fenomena yang dimaksud adalah variabel-variabel. Instrumen penelitian yang digunakan adalah kuesioner. Butir pertanyaan atau pernyataan dalam kuesioner terkait dengan setiap indikator-indikator diharuskan dijawab oleh setiap responden

Alternatif jawaban tersedia untuk dipilih salah satu dari setiap pertanyaan atau pernyataan, dengan cara memilih jawaban singkat dalam bentuk skala peringkat (rating scale) dari tunjangan kinerja terhadap kinerja pegawai. Skala peringkat termaksud adalah Skal Likert yang digunakan untuk mengukur sikap, pendapat, dan persepsi seseorang tentang variabel penelitian serta mudah untuk dijawab (Sugiyono, 2013). Pengukuran yang akan digunakan dalam penelitian ini menggunakan skala $1 \mathrm{~s} / \mathrm{d} 5$, dimana setiap butir pertanyaan/pernyataan akan diberikan: (a) Skor 1 untuk jawaban responden sangat tidak setuju; (b) Skor 2 untuk jawaban responden tidak setuju; (c) Skor 3 untuk jawaban responden antara setuju dan tidak setuju; (d) Skor 4 untuk jawaban responden setuju; dan (e) Skor 5 untuk jawaban responden sangat setuju. Data yang dikumpulkan melalui angket akan dianalisis dengan alat analisis variance SPSS untuk mengetahui pengaruh 
variabel independen terhadap variabel dependen.

\section{Prosedur Pengumpulan Data}

Penelitian ini merupakan penelitian terhadap fakta berupa opini atau pendapat orang (responden). Maka jenis data yang digunakan adalah data subyek. Data subjek adalah jenis data penelitian yang berupa opini, sikap, pengalaman atau karakteristik dari seseorang atau sekelompok orang yang menjadi subyek penelitian (responden).

Sumber data yang digunakan dalam penelitian ini terdiri dari data primer dan data sekunder, sebagai berikut: (1). Data Primer yaitu data yang berasal dari sumber yang asli dan dikumpulkan secara khusus untuk menjawab penelitian ini (Soeratno dan Arsyad, 2003: 76). Data primer yang ada dalam penelitian ini merupakan data kuesioner dari pegawai Poltek KP Sorong; dan (2) Data Sekunder yaitu data yang diperoleh dari sekumpulan sumber lain, baik dari dalam maupun luar Instansi (Soeratno dan Arsyad, 2003: 76). Data sekunder pada penelitian ini terdiri dari: buku, jurnal, dan sumber-sumber lainnya yang berkaitan dan memperkuat dasar penelitian serta sumber-sumber tertulis yang mengacu pada teori-teori yang ada. Pengumpulan data di sini ditujukan untuk memperoleh skor yang berfungsi sebagai arah hubungan pemberian tunjangan, dan kinerja pegawai Poltek KP Sorong.

Teknik pengumpulan data yang digunakan dalam penelitian ini terdiri dari: (a) Wawancara, dengan mengajukan pertanyaan secara langsung kepada pegawai; (b) Kuesioner, dengan membuat daftar pertanyaan yang diajukan kepada responden. (c) Observasi, dengan menga dakan pengamatan secara langsung terhadap objek penelitian.

\section{Metode Analisis Data}

Untuk menganalisis data, peneliti menggunakan statistik deskriptif, dengan maksud untuk mencari kuatnya hubungan antar variabel melalui analisis korelasi dengan analisis regresi, dengan membuat perbandingan dengan membandingkan rata-rata data sampel atau populasi.

\section{Variabel Penelitian Yang di Analisis}

Variabel yang diteliti dalam penelitian ini adalah pengaruh Tunjangan Kinerja terhadap Kinerja Pegawai dapat dijelaskan seperti berikut yaitu Tunjangan Kinerja (X) merupakan tunjangan yang diberikan kepada pegawai berdasarkan capaian kinerja. Tunjangan Kinerja dapat diketahui dari indikator yang meliputi: a) Pegawai mendapatkan tunjangan tepat 
waktu, b) Pegawai mendapat tunjangan langsung melalui rekening, c) Pegawai menerima tunjangan sesuai jumlah yang ditetapkan, dan d) Pegawai selalu mendapat tunjangan. Lebih rinci, kinerja terbangun dari unsur-unsur berikut: (a) Kuantitas, yaitu jumlah yang harus diselesaikan atau dicapai. Pengukuran kuantitatif melibatkan perhitungan keluaran dari proses atau pelaksanaan kegiatan. Ini berkaitan dengan jumlah keluaran yang dihasilkan. (b) Kualitas, yaitu mutu yang harus dihasilkan (baik tidaknya). Pengukuran kualitatif keluaran mencerminkan pengukuran "tingkat kepuasan” yaitu seberapa baik penyelesaiannya. Ini berkaitan dengan bentuk keluaran. (c) Ketepatan waktu, yaitu sesuai dengan waktu yang direncanakan. Pengukuran ketepatan waktu merupakan jenis khusus dari pengukuran kuantitatif yang menentukan ketepatan waktu penyelesaian suatu kegiatan. (d) Proses pelaksanaan kegiatan harus sesuai dengan proses yang telah dicanangkan. (e) Personil harus mempertanggungjawabkan keseluruhan kegiatan yang telah dilakukannya kepada pimpinan.

\section{Uji Persyaratan Analisis}

Uji persyaratan analisis dilakukan dengan maksud memberikan gambaran tentang sejauh mana persyaratan telah dipenuhi sesuai dengan teknik analisis yang telah direncanakan. Berdasarkan tujuan penelitian ini, teknik analisis yang digunakan adalah teknik analisis regresi ganda. Sedangkan asumsi yang harus dipenuhi adalah (a) distribusi bersyarat variabel dependen bagi tiap kombinasi variabel independen memiliki variansi yang sama; (b) nilai-nilai variabel dependen harus independen antara satu dengan yang lain (Pedhazur, 1982:33; Lewis, R. Binford., 1980; Dajan, 1986). Berikut beberapa pengujian yang harus dipenuhi sebelum analisis dilakukan antara lain uji validitas dan reliabilitas.

Validitas adalah suatu ukuran yang menunjukkan tingkat kesahihan suatu instrumen penelitian (Arikunto, 2000). Suatu instrumen penelitian yang valid memiliki validitas yang tinggi, sebaliknya instrumen yang kurang valid berarti memiliki validitas yang rendah. Uji validitas yang digunakan dalam tesis ini adalah validitas item kuesioner. Validitas item digunakan untuk mengukur ketepatan atau kecermatan suatu item dalam mengukur apa yang ingin diukur. Item yang valid ditunjukkan dengan adanya korelasi antara item terhadap skor total item. Untuk menentukan apakah suatu item layak digunakan atau tidak, adalah dengan melakukan uji signifikansi koefisien 
korelasi pada taraf signifikansi 0,05 , yang artinya suatu item dianggap valid jika berkorelasi signifikan terhadap skor total item. Bisa juga dengan melakukan penilaian langsung terhadap koefisien korelasi yakni dengan menggunakan batas nilai minimal korelasi 0,30 (Azwar, 1999). Masih menurut Azwar (1999) semua item yang mencapai koefisien korelasi minimal 0,30 memiliki daya pembeda yang memuaskan.

Suatu alat ukur dikatakan reliabel apabila dalam mengukur suatu gejala pada waktu yang berlainan alat itu senantiasa menunjukkan hasil yang sama. Jadi alat yang reliabel secara konsisten memberi hasil ukuran yang sama. Metode uji reliabilitas yang sering digunakan adalah Cronbach's Alpha. Metode ini sangat cocok digunakan pada skor berbentuk skala atau skor rentangan.

\section{Menurut Uma Sekaran (2003)} pengambilan keputusan untuk uji reliabilitas sebagai berikut: (a) Cronbach's Alpha $<0,6=$ reliabilitas buruk; (b) Cronbach's Alpha $0,6-0,79=$ reliabilitas diterima; dan (c) Cronbach's Alpha 0,8= reliabilitas baik. Sedangkan menurut Nunnally seperti dikutip oleh Imam Ghazali (2005), alat ukur dapat dikatakan reliabel jika nilai reliabilitas $>0,600$, di mana 0,600 adalah standarisasi nilai reliabilitas menurut pernyataan Nunnally.

\section{Uji Hipotesis}

\section{Uji T dengan Analisis Regresi Parsial}

Analisis Regresi Parsial adalah analisis tentang hubungan antara variabel bebas (independent variable) dengan satu variabel terikat (dependent variable). Analisis regresi ganda bertujuan untuk memprediksi nilai pengaruh dua variabel bebas terhadap satu variabel terikat dengan menggunakan persamaan regresi sebagai berikut:

$$
\mathrm{Y}=\mathrm{a}+\beta . \mathrm{X}
$$

Keterangan:

$$
\begin{aligned}
& \mathrm{Y}=\text { kinerja pegawai } \mathrm{a}=\text { konstanta } \\
& \mathrm{b}=\text { koefisien regresi dari variabel } \mathrm{X}
\end{aligned}
$$$$
\text { X = Tunjangan Kinerja (Arikunto, 1998) }
$$

Analisis korelasi ganda dapat dicari jauh lebih efisien melalui regresi ganda (Sutrisno Hadi 2001:132). Analisis regresi ganda dilakukan dengan bantuan SPSS versi 17. Pengambilan keputusan didasarkan angka probabilitas. Jika angka $\mathrm{F}$ hitung > F tabel, maka hipotesis nihil (H0) ditolak dan hipotesis kerja (Hk) diterima. 
HASIL DAN PEMBAHASAN

\section{Uji Validitas}

Validitas adalah kesesuaian alat ukur dengan apa yang diukur atau sebuah instrumen dikatakan valid jika mampu mengukur apa yang diinginkan dan dapat mengungkap data dari variabel yang diteliti secara tepat. Hasil uji validitas dari penelitian ini dapat dilihat pada Tabel 1.

Tabel 1 Uji Validitas Variabel Tunjangan Kinerja (X1)

\begin{tabular}{|c|c|c|c|c|c|c|}
\hline \multicolumn{7}{|c|}{ Correlations } \\
\hline & & X 1 & X 2 & X 3 & $\mathrm{X} 4$ & $\mathrm{X}$ \\
\hline \multirow[t]{4}{*}{ X 1} & Pearson & 1 & $0,779^{* *}$ & 0,200 & $0,895^{* *}$ & $0,919^{* *}$ \\
\hline & Correlation & & & & & \\
\hline & Sig. (2-tailed) & & 0,000 & 0,133 & 0,000 & 0,000 \\
\hline & $\mathrm{N}$ & 58 & 58 & 58 & 58 & 58 \\
\hline \multirow[t]{3}{*}{ X 2} & Pearson & $0,779^{* *}$ & 1 & $0,425^{* *}$ & $0,583^{* *}$ & $0,872^{* *}$ \\
\hline & Sig (2-tailed) & 0.000 & & 0,001 & 0.000 & 0,000 \\
\hline & $\mathrm{N}$ & 58 & 58 & 58 & 58 & 58 \\
\hline \multirow[t]{4}{*}{ X 3} & Pearson & 0,200 & $0,425^{* *}$ & 1 & 0,209 & $0,532^{* *}$ \\
\hline & Correlation & & & & & \\
\hline & Sig. (2-tailed) & 0,133 & 0,001 & & 0,116 & 0,000 \\
\hline & $\mathrm{N}$ & 58 & 58 & 58 & 58 & 58 \\
\hline \multirow[t]{3}{*}{ X 4} & $\begin{array}{l}\text { Pearson } \\
\text { Correlation }\end{array}$ & $0,895^{* *}$ & $0,583^{* *}$ & 0,209 & 1 & $0,862^{* *}$ \\
\hline & Sig. (2-tailed) & 0,000 & 0,000 & 0,116 & & 0,000 \\
\hline & $\mathrm{N}$ & 58 & 58 & 58 & 58 & 58 \\
\hline \multirow[t]{3}{*}{$\mathrm{X}$} & Pearson & $0,919^{* *}$ & $0,872^{* *}$ & $0,532^{* *}$ & $0,862^{* *}$ & 1 \\
\hline & Sig. (2-tailed) & 0,000 & 0,000 & 0,000 & 0,000 & \\
\hline & $\mathrm{N}$ & 58 & 58 & 58 & 58 & 58 \\
\hline
\end{tabular}

Tabel 2. Uji Validitas Variabel Kinerja Pegawai (Y)

\begin{tabular}{|c|c|c|c|c|c|c|c|}
\hline \multicolumn{8}{|c|}{ Correlations } \\
\hline & & Y 1.1 & Y 1.2 & $\begin{array}{ll}\text { Y } 1.3 \\
\end{array}$ & Y 1.4 & Y 1.5 & $\bar{Y}$ \\
\hline \multirow[t]{4}{*}{ Y 1} & Pearson & 1 & 0,529 & 0,506 & 0,905 & 0,608 & 0,900 \\
\hline & Correlation & & & & & & \\
\hline & Sig. (2-tailed) & & 0,000 & 0,000 & 0,000 & 0,000 & 0,000 \\
\hline & $\mathrm{N}$ & 58 & 58 & 58 & 58 & 58 & 58 \\
\hline \multirow[t]{4}{*}{ Y 2} & Pearson & 0,529 & 1 & 0,814 & 0,633 & 0,083 & 0,792 \\
\hline & Correlation & & & & & & \\
\hline & Sig. (2-tailed) & 0,000 & & 0,000 & 0,000 & 0,536 & 0,000 \\
\hline & $\mathrm{N}$ & 58 & 58 & 58 & 58 & 58 & 58 \\
\hline \multirow[t]{4}{*}{ Y 3} & Pearson & 0,506 & 0,814 & 1 & 0,762 & - & 0,777 \\
\hline & Correlation & & & & & 0,133 & \\
\hline & Sig. (2-tailed) & 0,000 & 0,000 & & 0,000 & 0,321 & 0,000 \\
\hline & $\mathrm{N}$ & 58 & 58 & 58 & 58 & 58 & 58 \\
\hline \multirow[t]{2}{*}{ Y 4} & Pearson & 0,905 & 0,633 & 0,762 & 1 & 0,431 & 0,958 \\
\hline & Correlation & & & & & & \\
\hline
\end{tabular}


Noken Vol. 6 (No. 1) Halaman 1-12 2020

\begin{tabular}{|c|c|c|c|c|c|c|c|}
\hline & Sig. (2-tailed) & 0,000 & 0,000 & 0,000 & & 0,001 & 0,000 \\
\hline & $\mathrm{N}$ & 58 & 58 & 58 & 58 & 58 & 58 \\
\hline \multirow[t]{4}{*}{ Y 5} & Pearson & 0,608 & 0,083 & & 0,431 & 1 & 0,480 \\
\hline & Correlation & & & 0,133 & & & \\
\hline & Sig. (2-tailed) & 0,000 & 0,536 & 0,321 & 0,001 & & 0,000 \\
\hline & $\mathrm{N}$ & 58 & 58 & 58 & 58 & 58 & 58 \\
\hline \multirow[t]{3}{*}{ Y } & $\begin{array}{l}\text { Pearson } \\
\text { Correlation }\end{array}$ & 0,900 & 0,792 & 0,777 & 0,958 & 0,480 & 1 \\
\hline & Sig. (2-tailed) & 0,000 & 0,000 & 0,000 & 0,000 & 0,000 & \\
\hline & $\mathrm{N}$ & 58 & 58 & 58 & 58 & 58 & 58 \\
\hline
\end{tabular}

Dari hasil uji validitas pada Tabel 1 2 didapat dua output dari yang pertama adalah variabel Tunjangan Kinerja (X), dan variabel Kinerja Pegawai (Y). Dari output tersebut dapat diketahui nilai korelasi antara tiap item dengan skor total item. Nilai korelasi ini dibandingkan dengan $r$ tabel. $r$ tabel dicari pada signifikansi 0,05 dengan uji 2 sisi dan jumlah data (n) 58, maka didapat $r$ tabel sebesar 0,258. Jadi nilai $r$ tabel dengan $\alpha$ $5 \%$ dan jumlah untuk uji validitas Tunjangan Kinerja, dan Kinerja Pegawai Poltek KP Sorong adalah 0,258. Berdasarkan hasil analisis, dapat disimpulkan bahwa item-item yang digunakan dalam penelitian ini valid. Hasil rangkuman dari uji validitas dapat dilihat pada Tabel berikut:

Tabel 3. Rangkuman Uji Validitas Variabel Data Tunjangan Kinerja

\begin{tabular}{cccc}
\hline No Item & rX & r tabel & Keterangan \\
\hline 1 & 0,919 & 0,258 & Valid \\
2 & 0,872 & 0,258 & Valid \\
3 & 0,532 & 0,258 & Valid \\
4 & 0,862 & 0,258 & Valid \\
\hline
\end{tabular}

Sumber: Diolah dari Hasil Analisis

Tabel 4. Rangkuman Uji Validitas Variabel Data Kinerja Pegawai

\begin{tabular}{cccc}
\hline No Item & rY & r tabel & Keterangan \\
\hline 1 & 0,900 & 0,258 & Valid \\
2 & 0,792 & 0,258 & Valid \\
3 & 0,777 & 0,258 & Valid \\
4 & 0,958 & 0,258 & Valid \\
5 & 0,480 & 0,258 & Valid \\
\hline
\end{tabular}

Sumber: Diolah dari Hasil Analisis

\section{Uji Reliabilitas}

Reliabilitas adalah kekonsistenan alat ukur yang digunakan. Suatu indikator dikatakan reliabel jika alat itu dalam mengukur suatu gejala pada waktu yang berlainan senantiasa menunjukkan hasil 
yang sama. Atau suatu indikator dikatakan reliabel jika nilai reliabilitasnya > 0,6. Jadi alat yang reliabel secara konsisten memberi hasil ukuran yang sama (Dewi, October 2018). Metode uji reliabilitas yang digunakan adalah cronbach's alpha. Dari hasil uji reliabilitas seperti terdapat pada Tabel $3-4$ didapat tiga output dari yang pertama adalah variabel Tunjangan Kinerja (X), dan variabel Kinerja Pegawai (Y). Dari output tersebut dapat diketahui nilai reliabilitas (Cronbach's Alpha) tiap variabel. Untuk variabel Tunjangan Kinerja (X) nilai Cronbach's Alpha sebesar 0,819, dan untuk variabel Kinerja Pegawai (Y) nilai Cronbach's Alpha sebesar 0,837. Karena nilai kedua variabel tersebut di atas 0,6 maka dapat disimpulkan bahwa alat ukur dalam penelitian tersebut reliabel.

\section{Uji Hipotesis}

\section{Uji t (Uji Koefisien regresi secara parsial)}

Uji $\mathrm{t}$ digunakan untuk mengetahui apakah variabel independen secara parsial berpengaruh terhadap variabel dependen. Pada bagian ini akan dilakukan pengujian terhadap variabel Tunjangan Kinerja dan Motivasi.

Sebelum pengujian regresi dilakukan, maka terlebih dahulu peneliti menentukan hipotesis dari variabel ini. Adapun hipotesis yang digunakan untuk variabel Tunjangan Kinerja adalah sebagai berikut:

H0: Secara parsial tunjangan kinerja tidak berpengaruh terhadap kinerja pegawai.

H1: Secara parsial tunjangan kinerja berpengaruh terhadap kinerja pegawai.

Berdasarkan output pada tabel 4.9 diperoleh $\mathrm{t}$ hitung sebesar -0,592. Tabel distribusi t dicari pada $\alpha=5 \%: 2=2,5 \%$ (uji 2 sisi) dengan derajat kebebasan (df) n-k-1 atau 58-2-1 = 55 (n adalah jumlah data dan $\mathrm{k}$ adalah jumlah variabel independen). Dengan pengujian 2 sisi ( signifikansi $=0,025)$ maka diperoleh hasil untuk $t$ tabel sebesar 2,004.

Pada kriteria pengujian Ho diterima jika $-\mathrm{t}$ tabel $\leq \mathrm{t}$ hitung $\leq \mathrm{t}$ tabel dan Ho ditolak jika -t hitung < - t tabel atau t hitung $>\mathrm{t}$ tabel. Pada pengujian terhadap variabel tunjangan kinerja hasil yang diperoleh menunjukkan bahwa nilai $\mathrm{t}$ hitung $<\mathrm{t}$ tabel $(0,592<2,004)$, maka Ho diterima; artinya bahwa secara parsial tunjangan kinerja tidak berpengaruh terhadap kinerja pegawai.

\section{KESIMPULAN}

Berdasarkan penelitian yang dilakukan, diperoleh hasil bahwa Tunjangan kinerja (X), dengan keseluruhan komponen pembentukannya tidak berpengaruh terhadap Kinerja 
pegawai (Y), sehingga hipotesis pertama yang menyatakan bahwa tunjangan kinerja $(\mathrm{X})$ berpengaruh terhadap Kinerja pegawai (Y) tidak terbukti. Hal ini didasarkan pada koefisien regresi variabel budaya organisasi di mana diperoleh hasil sebesar 0,185; artinya, jika budaya organisasi mengalami kenaikan satu satuan, maka kinerja pegawai akan mengalami kenaikan sebesar 0,185. Penelitian ini mengindikasikan bahwa Pegawai Poltek KP Sorong dalam bekerja bukan karena tunjangan. Pegawai harus bekerja dengan atau tanpa tunjangan dan meningkatkan motivasi agar kinerja juga meningkat. Nilai-nilai organisasi harus dihidupi oleh setiap pegawai dalam bekerja. Apabila pegawai bekerja karena tunganjan, maka tujuan organisasi tidak akan tercapai dengan baik. Setiap pegawai harus memiliki motivasi yang kuat dalam dirinya agar dapat bekerja secara maksimal. Sehingga dapat disarankan bahwa hasil ini dapat menjadi bahan pertimbangan bagi Poltek KP Sorong guna mendukung konsep dan teori yang sudah mapan sebelumnya, sehingga konsep dan teori yang berkaitan dengan tunjangan kinerja, Kinerja Pegawai dapat menjadi referensi peningkatan kinerja pegawai Poltek KP Sorong baik secara parsial maupun integral.

UCAPAN TERIMAKASIH
Ucapan terimakasih terhadap Keluarga Tercinta dan Juga Kampus Politeknik KP Sorong.

\section{DAFTAR PUSTAKA}

Arikunto. 2006. Prosedur Penelitian Suatu Pendekatan Praktek. PT. Rineka Cipta. Jakarta.

Azwar, S. (1999). Penyusunan skala psikologi. Pustaka pelajar.

Binford, L. R. (1980). Willow smoke and dogs' tails: hunter-gatherer settlement systems and archaeological site formation. American antiquity, 4-20.

Dajan, A. (1986). Pengantar metode statistik jilid I. Jakarta: LP3ES.

Ghozali, I. (2005). Aplikasi analisis multivariate dengan SPSS. Semarang: Badan Penerbit UNDIP.

Najoan, J. F., L. R. J. Pangemanan., E. G. Tangkere. 2018. Pengaruh Tunjangan Kinerja Terhadap Kinerja Pegawai Pada Dinas Pertanian Kabupaten Minahasa. Agri-Sosio Ekonomi Unsrat, ISSN 1907- 4298, Volume 14 Nomor 1, Januari $2018: 11-24$ halaman.

Peraturan Pemerintah Republik Indonesia Nomor 58 Tahun 2005 Tentang Pengelolaan Keuangan Daerah. 70 Halaman.

Peraturan Menteri Kelautan Dan Perikanan Republik Indonesia Nomor 16/Permen-KP/2018 Tentang Tata Cara Pembayaran Tunjangan Kinerja Di Lingkungan Kementerian Kelautan Dan Perikanan. 30 Halaman. 
Peraturan Menteri Pendayagunaan Aparatur Negara Dan Reformasi Birokrasi Nomor 63 Tahun 2011 Tentang Pedoman Penataan Sistem Tunjangan Kinerja Pegawai Negeri. 28 Halaman.

Pedhazur, E.J. 1982. Multiple Regression in Behavioral Research. 2nd ed. Fort Worth, Text Holt Rinehart and Winston Inc.

Sugiyono, P. D. (2010). Metode penelitian pendidikan.

Kuantitatif.

Sugiyono, P. D. (2013). Metode penelitian manajemen. Bandung: Alfabeta, CV.

Soeratno \& Arsyad, L. (2003). Metodologi penelitian: untuk ekonomi dan bisnis. Universitas Yogyakarta. UPP Akademi Manajemen Perusahaan YKPN. Yogyakarta.

Hadi, S. (2001). Metodologi research untuk penulisan paper, skripsi (Doctoral dissertation, Thesis dan Disertasi, Jilid Tiga. Yogyakarta: Penerbit Andi).

Uma, S., \& Roger, B. (2003). Research methods for business: A skill building approach. book. http://www.bpsdmkp.kkp.go.id/index.php/ profil, 2018. dikutip pada tgl 13/08/2018, pukul 20:00 WIT.

http://.www.kkp.go.id, 2018. dikutip pada tgl 13/08/2018, pukul 20:20 WIT.

https://polteksorong.kkp.go.id, 2018. dikutip pada tgl 13/08/2018, pukul 20:10 WIT.

\section{PROFIL SINGKAT}

Penulis lahir di Pangkajene, Pangkep, Sulawesi Selatan, pada 14 Juli 1975, menempuh pendidikan di jenjang Sekolah Dasar hingga Menengah Umum di Pangkajene dari tahun 1987 - 1993, kemudian melanjutkan pendidikan pada program sarjana pada Program studi Ilmu Administrasi Negara di Universitas AlAmin Sorong (sekarang UM-Sorong) pada tahun 2004. Dan telah menyelesaikan Program Magister Administrasi Publik pada UPBJJ - Universitas Terbuka (UT) Sorong. Saat ini bekerja di Poltek KP Sorong pada unit kerja Sub Bagian Umum/Politeknik Kp Sorong/BRSDMKP, Kementerian Kelautan dan Perikanan. 